\title{
Ethnobotanical Survey of Edible Plants Sold in Katsina Metropolis Markets
}

\author{
Samaila Samaila Yaradua ${ }^{1}$, Monier Abd El-Ghani ${ }^{2}$ \\ ${ }^{1}$ Department of Biology, Umaru Musa Yaradua University, Katsina, P.M.B 2214 Dutsinma Road, Katsina State, Nigeria.
}

\begin{abstract}
Ethnobotanical survey was carried out to document food plants sold in Katsina metropolis Markets. The Three surveyed markets were: Kofar marusa market, Central Market and Tsohuwar Kasuwa market. Data were gathered through oral interviews with the food plant sellers using questionnaire especially designed for this purpose. Results obtained showed that a total of 54 plants belongs to 33 families were identified. Kofar Marusa Market has the highest plants species (40 plants species) followed by Tsohuwar Kasuwa market (39 plants species) and the least was Central Market (35 plants species) The most used plants were belonging to Fabaceae, (5 species), followed by Anacardiaceae, Solanaceae, Rutaceae, Cucurbitaceae and Poaceae (3 species each) Alliaceae, Aracaceae, Malvaceae, Sapotaceae (2 species). Other families included were Caricaceae, Zingiberaceae etc. Some of the plant species are of medicinal important amongst are Citrus limon treats deworms, Cocus nucifera treats Anti-poison/neutralizes poison, Measles, Allium sativum treats Cattarh, cold, cough and Antibiotic and other treats various diseases.
\end{abstract}

Keywords: Ethnobotanical survey, food plants, markets, medicinal plants

\section{Introduction}

Ethnobotany is the study of the relationship between plants and people: from "ethno" - study of people and "botany" study of plants. It is totally in virtually a new field of research, if in this field plants investigated thoroughly and systematically, it will yield result of great value of the archeologists, anthropologist, plant geographer, enthnobotanist, linguistics, botanists and phytochemists. The focus of ethnobotany is on how plants have been or are used, managed and perceived in human societies and includes plants used for food, medicine, cosmetics, dying, textiles, for building, tools, currency, clothing, rituals life and music. It also studies the relationship of a particular culture and region make of use of indigenous plants [1]. The relationship between plants and human cultures is not limited to the use of plants for food, clothing and shelter but also includes their use for religious ceremonies, ornamentation and health care [2]. In a particular ethnic group, information concerning certain plant varies from one ethnic group to another [3], [4]

In the past, ethnobotanical research was predominately a survey of the plants used by villagers. A trained botanist identified the plants and recorded their used. Sometimes an anthropologist was present to translate the disease description, but rarely was a physician available to identify the disease. The results generated a list of plants and their uses which was published in professional journal, usually in the country of the scientist. Nothing was communicated or returned to the cultural group in exchange for their participation in the survey, nor was any environmental or cultural status or concerns included in the survey. Basic quantitative and experimental ethnobotany includes basic documentation, quantitative evaluation of use and management and experimental assessment.

Today, ethnobotanical survey include applied projects that have the potential to ameliorate poverty levels of these people, allowing them to make more educated decisions about their future directions. These new approaches enhance the quality of the science, provide compensation for the cultural groups and take into account environmental concerns. This modern approach is based on an interdisciplinary team usually composed of an ethnobotanist, an anthropologist, an ecologist and a physician. Some of these team members are remote area colleagues who have arranged the details of the expedition as well as the contractual agreements for reciprocal programs of the village or community. The field of ethnobotany requires a variety of skills: botanical training for the identification and preservation of plants specimens; anthropological training to understand the cultural concept around the perception of plants; linguistic training, at least enough to transcribe local terms and understand native morphology, syntax and semantics. Native healers are often reluctant to accurately share their knowledge to outsiders [5].

The biological diversity of our world is great and we have only begun to investigate her potential. In some areas, diversity may be more valuable in its natural state that when used of pasture or timber [6]. Methods to identify medicinal plants include random screening, taxonomic collecting (sampling by botanical family) or ethnobotanical collecting. It has been shown that ethnobotanically-derived compound have greater activity that compounds derived from random screening and therefore a greater potential for product development. Plants are being used as valuable sources of food and medicine for the prevention of illness, and maintenance of human health.

The importance of plants in medicine remains even of greater relevance with the current global shift to obtain drugs from plant sources, as a result of which attention has been given to the medicinal value of herbal remedies for safety, efficacy and economy [7], [8]. The World Health Organization (WHO., 1992) emphasized the need to ensure the quality control of plant products by using modern techniques and applying suitable standards [9]

The indigenous traditional knowledge of medicinal plants of various ethnic communities, where it has been transmitted orally for centuries is fast disappearing from the face of the 


\section{International Journal of Science and Research (IJSR) \\ ISSN (Online): 2319-7064 \\ Index Copernicus Value (2013): 6.14 | Impact Factor (2014): 5.611}

earth due to the advent of modern technology and transformation of traditional culture. There is an urgent need to document the ethno-biological information presently existing among the diverse communities before the traditional knowledge are completely lost [10]. Much of this wealth of knowledge is totally becoming lost as traditional culture gradually disappears [11]. Thus, there is now urgency for ethno-botanical research amongst people [12].

In recent years, traditional ethno-botanical studies have received much attention due to their wide local acceptability and clues for new or less known medicinal plants [13]. The collection of information about natural flora, classification, management and use of plants by the people holds importance among the ethno botanists.

The aim (s) of the research are as follows: -

1) To identify and document edible plants sold in Katsina metropolis markets

2) To identify and access the major ethno-medicinal plants of the study area so as to document the indigenous knowledge and use of ethno-medicinal plants in the treatment of various human ailments.

\section{Methodology}

\subsection{Study Area}

Katsina $\left(12^{\circ} 59^{\circ} \mathrm{N}, 7^{\circ} 36^{\circ} \mathrm{E}\right)$; with a total area of $142 \mathrm{~km}^{2}$; is a city (formerly a city-state), and a Local Government Area in northern Nigeria, and is the capital of Katsina State. It is located some $256,50 \mathrm{~km}$ east of the city of Sokoto, 135,18 $\mathrm{km}$ northwest of Kano, close to the border with Niger. As of 2007, Katsina's estimated population was 459,022 (2006 population census). The city is the centre of an agricultural region producing groundnuts, cotton, hides, millet and guinea corn, and also has mills for producing peanut oil and steel. The city is largely Muslim and the population of the city is mainly from the Fulani and Hausa ethnic groups. The survey was carried out in three market of katsina metropolis; namely Kofar Marusa Market, Central Market and Tsohuwar kasuwa market.

\subsection{Method of Data Collection}

The field methodological framework chosen for this research was that used in ethnobiology [14]-[16]and based on methods given by [17], semi-structured interviewees, observation and guided field walks with informants were employed to obtain ethnobotanical data. Field research was conducted by collecting ethnobotanical information during structured and semi-structured interviews with knowledgeable people native in each site territory. For each plant recorded one questionnaire was filled. Even though, a structured questionnaire had to be filled direct questions were avoided. The basic information needed was taken during the conversation.

No special selection criteria were used in the choice of the informants because one of the aims of this work was to assess the breadth of popular heritage in the field of wild edible plants, knowledge which is widespread among locals.
However, most of the interviewees were between 40-60 years old, and are not settlers of Katsina metropolis.

Plant data and their related information were entered into a data base. The data acquired for each plant comprise the common local name, its uses, the part of the plant used. Frequency $(\mathrm{F} \%)$ of each of the collected plant species was estimated as the total number of its records in the studied markets.

The way plants were collected, preserved, stored and the most relevant processes were photographed. The data collected were derived from questionnaire administration and oral interview of the food plants sellers in Kofar marusa market, Central Market and Tsohuwar Kasuwa market. The respondents were both men and women of various ages. Data obtained were collated and arranged to give the botanical names, common names, families and the local names as well as their uses and the part(s) used.

During oral interview the questions to the respondents are their names, name of plants he/she is selling, knowledge of medicinal uses of the plants, part used and the use of the plants. The respondents cooperate in answering questions. During the survey plants that of ethnomedicinal important are also included, food plants sellers that has knowledge on ethnomedicinal plants are interviewed for local name of the plant, part used and disease cure by the plant.

Plant identification was given by Professor Monier Abd ElGhani, consulting different available literature on ethnobotanical surveys in Nigeria.

\section{Results}

A total of 54 plant species belongs to 33 families were identified from the 3 studied markets (Table 1). The total number of species varied from one market to another: 35 in Central Market, 40 in Kofar Marusa Market, and 39 in Tsohuwar Kasuwa Market.

Eighteen species were constantly recorded from all the three studied markets $(\mathrm{F}=100 \%)$ including amongst others Hibiscus esculentus, Allium sativum, Magnifera indica and Capsicum annum. Twenty five species were recorded in two markets $(\mathrm{F}=66.66 \%)$, amongst others, Brassica oleracea var. capitata (Market 1 and 2), Crysophylum albedom (Market 2 and 3), Vernomia amygdalina (Market 1 and 3). Ten species were recorded only in one market $(\mathrm{F}=33.33 \%)$, of which six species were occurred in Market 1, and 4 species in Market 2 (see Table 2).

The most used plants was belonging to Fabaceae ( 5 species), among which are Arachis hypogeea, Tamarindus indica and Parkia biglobosa were recorded. Anacardiaceae (3 species), among which Magnifera indica and Anarcadium occidentale were recognized. Solanaceae (3 species), of which Capsicum annum and Lycopersicum esculentum can be mentioned. Rutaceae (3 species) included Citrus sinensis and Cintrus limon were recorded. Cucurbitaceae (3 species) among which Cucurbita maxima and Citrullus lanatus were recognized. Poaceae (3 species) among which are Oryza sativa, zea mays. Alliaceae which are Allium cepa and 


\section{International Journal of Science and Research (IJSR) \\ ISSN (Online): 2319-7064 \\ Index Copernicus Value (2013): 6.14 | Impact Factor (2014): 5.611}

Allium sativum Aracaceae which are Cocus nucifera and Ealais guinensis. Malvaceae which are Hibiscus sabdariffa and Hibiscus esculentus. Sapotaceae (2 species) which included Vitalleria paradoxa and Crysophylum albedum. Similar observation can be made on the other families. Fruits of twenty four species were used, these included Magnifera indica, Anarcadium occidentale and Capsicum annum. Leaves of 9 species were used such as Amaranthus caudatus, Adansonia digitata and Crateva religiosa. Seeds of four species were used included Arachis hypogea and Phaseolus vulgaris. The least used plant parts were nuts, tuber (two species of each). Some of the plant species were used to treat various diseases amongst were Citrus limon treats deworms, Cocus nucifera treats Antipoison/neutralizes poison, Measles, Allium sativum treats Cattarh, cold, cough and Antibiotic, and others can be used to treat different diseases (Table 2).

Table 1: Local name, Scientific name, Common name, family name and part used of each plant species.

\begin{tabular}{|c|c|c|c|c|c|c|c|c|}
\hline Scientific Name & Common Name & Family & Local Name & Part used & 1 & 2 & 3 & $F \%$ \\
\hline Hibiscus esculentus & Okra & Malvaceae & Kubewa & seeds,young pods & + & + & + & 100 \\
\hline Allium sativum & Garlic & Alliaceae & Ramuza & flowers, leaves,seeds & + & + & + & 100 \\
\hline Allium cepa & Onion & Alliaceae & Albasa & Bulb & + & + & + & 100 \\
\hline Amaranthus caudatus & Waterleaf & Amaranthaceae & Alayyafoo & leaves, seeds & + & + & + & 100 \\
\hline Anarcadium occidentale & Cashew & Anarcardiaceae & Yazawa & Fruit & + & + & + & 100 \\
\hline Arachis hypogea & Groundnut & Fabaceae & Gyada & Seeds & + & + & + & 100 \\
\hline Capsicum annum & Chili pepper & Solanaceae & Tattasai & Fruit & + & + & + & 100 \\
\hline Citrus limon & Lime & Rutaceae & Lemun tsami & fruit,juice & + & + & + & 100 \\
\hline Citrus paradise & Grape & Rutaceae & Lemu yamiku & Seeds & + & + & + & 100 \\
\hline Cucurbita maxima & Pumpkin & Cucurbitacea & Kabeewaa & Fruit & + & + & + & 100 \\
\hline Hibiscus sabdariffa & Roselle & Malvaceae & Yakuwa & leaves,flower & + & + & + & 100 \\
\hline Lycopersicum esculentum & Tomato & Solanaceae & Tumatur & Fruit & + & + & + & 100 \\
\hline Magnifera indica & Mango & Anarcardiaceae & Mangwaro & Fruit & + & + & + & 100 \\
\hline Manihot esculanta & Cassava & Euphorbiaceae & Rogo & Tubers & + & + & + & 100 \\
\hline Oryza sativa & Rice & Poaceae & Shinkafa & Grains & + & + & + & 100 \\
\hline Solanum melongena & Garden-egg & Solanaceae & Yalo & Fruit & + & + & + & 100 \\
\hline Zea mays & Maize & Poaceae & Masara & silk, corn & + & + & + & 100 \\
\hline Zingiber officinale & Ginger & Zingiberaceae & Citta & Root & + & + & + & 100 \\
\hline Adansonia digitata & Baobab & Bombaceae & Kuka & leave, fruit & - & + & + & 66.66 \\
\hline Annona senegalansis & Wild custard apple & Annonaceae & Gwandan daji & fruit, leaves & + & + & - & 66.66 \\
\hline Brassica oleracea var. capitata & Cabbage & Brassicaceae & Kabeji & leaves & + & + & - & 66.66 \\
\hline Citrus sinensis & Orange & Rutaceae & Lemun Zaki & Fruit & + & - & + & 66.66 \\
\hline Cocus nucifera & Coconut & Arecaceae & Mosara & Nut & - & + & + & 66.66 \\
\hline Cola nitida & Kolanut & Sterculiaceae & Goro & Fruit & - & + & + & 66.66 \\
\hline Colocynthis citrullusegusi & Melon seeds & Cucurbitaceae & Agushii & Seeds & + & - & + & 66.66 \\
\hline Crateva religiosa & Sacred barma & Capparaceae & Ungududu & Leaves & - & + & + & 66.66 \\
\hline Crysophylum albedum & Star apple & Sapotaceae & Agwaliba & Fruit & - & + & + & 66.66 \\
\hline Daucus carota & Carrot & Apiaceae & Karas & Root & + & + & - & 66.66 \\
\hline Dioscorea alata & Water yam & Dioscoreaceae & Dugura & Tubers,leaves & + & - & + & 66.66 \\
\hline Ealais guinensis & Palm kernel & Arecaceae & Kwakwa & Nut & + & - & + & 66.66 \\
\hline Euphorbia balsamifera & Spurge & Euphorbiaceae & Aliyara & Leaves & - & + & + & 66.66 \\
\hline Ficus exasperate & & Moraceae & Baure & Fruit & - & + & + & 66.66 \\
\hline Moringa oleifera & Horseradish & Moringaceae & Zogale & Leaves & - & + & + & 66.66 \\
\hline Parkia biglobosa & Locust bean seed & Fabaceae & Kalwa & Fruit & - & + & + & 66.66 \\
\hline Phaseolus vulgaris & Grean bean & Fabaceae & Grean bean & Seeds & + & + & - & 66.66 \\
\hline Piper guinenses & Black pepper & Piperaceae & Uda & seeds, leaves & + & - & + & 66.66 \\
\hline Psidium guajava & Guava & Myrtaceae & Gwaba & Fruit & - & + & + & 66.66 \\
\hline Saccarum officinarum & Sugar cane & Poaceae & Rake & Stem & - & + & + & 66.66 \\
\hline Tamarindus indica & Tamarind & Fabaceae & Tsamiya & Fruit & - & + & + & 66.66 \\
\hline Vernomia amygdalina & Bitter leaf & Asteraceae & Shuwaka & Leaves & + & - & + & 66.66 \\
\hline Vitalleria paradoxa & Shea tree & Sapotaceae & Kadanya & Fruit & - & + & + & 66.66 \\
\hline Xanthosoma sagittifolium & Cocoyam & Araceae & Gwaza & root & - & + & + & 66.66 \\
\hline Citrullus lanatus & Water melon & Cucurbitacea & Kankana & Fruit & + & - & - & 66.66 \\
\hline Ananas comusus & Pineapple & Bromeliaceae & Abarba & Fruit & + & - & - & 33.33 \\
\hline Carica papaya & Pawpaw & Caricaceae & Gwanda & Fruit & + & - & - & 33.33 \\
\hline Diospyros mespiliforms & Jacka berry & Ebanaceae & Kanya & fruit,leaves & - & + & - & 33.33 \\
\hline Lannea microcarpa & Dahomey & Anarcardiaceae & Faru & Fruit & + & - & - & 33.33 \\
\hline Leptadenia hastate & & Aslepiadaceae & Yadiya & Leaves & - & + & - & 33.33 \\
\hline Musa paradisiacal & Plantain & Musaceae & Ayaba & Fruit & + & - & - & 33.33 \\
\hline Musa sapientum & Banana & Musaceae & Ayaba & Fruit & + & - & - & 33.33 \\
\hline Parinari macrophylla & Tree & Chrysobalanaceae & Gawasa & Fruit & - & + & - & 33.33 \\
\hline Senna obtusifolia & Sickle pod & Fabaceae & Tafasa & Leaves & - & + & - & 33.33 \\
\hline Sesanum orientale & Sesame leaves & Pedaliaceae & Karkashi & Leaves & + & - & - & 33.33 \\
\hline
\end{tabular}




\section{International Journal of Science and Research (IJSR) \\ ISSN (Online): 2319-7064}

Index Copernicus Value (2013): 6.14 | Impact Factor (2014): 5.611

Market $1=$ Central Market

Market 2= Kofar Marusa Market

Market 3= Tsohuwar Kasuwa Market

$+=$ Present; - = Absent

Table 2: Some major ethnomedicinal plants of Katsina metropolis, their Botanical/Local names, Medicinal used and part used

\begin{tabular}{|c|c|c|c|}
\hline Scientific Name & Local name & Medicinal uses & Part used \\
\hline Hibiscus esculentus & Kubewa & Sperm count fever & Fruit leaves \\
\hline Allium сера & Albasa & Hypertension, measles and cough & Bulb \\
\hline Allium sativum & Tafarnuwa & Cattarh, cold, cough and Antibiotic & Bulb \\
\hline Amaranthus caudatus & Alaiyafoo & Blood tonic & Leaves \\
\hline Ananas comusus & Abarba & Anti-hypertension/constipation & Unripe fruit \\
\hline Anarcadium occidentale & Yazawa & High cough & Bark, Fruit \\
\hline Annona senegalansis & Gwandan daji & Snake bite, yellow fever and hernia & Stem \\
\hline Anogeissus leiocarpus & Marke & Ulcer/Pile & Bark \\
\hline Azadiracta indica & Dogon yaro/Bedi & Yellow fever & Leaves \\
\hline Balanites aegyptiaca & Aduwa & Bladder stone & Fruit \\
\hline Boswelia dalzelia & Hano & Yellow fever & Bark,leaves \\
\hline Calotropis procera & Tumfafiya & Scorpion sting, finger ache (witlow) & Leaves \\
\hline Carica papaya & Gwanda & Boil purgative & Unripe fruit \\
\hline Cassia tora & Tafasa & Pile and stomach trouble & Leaves \\
\hline Citrullus lanatus & Kankana & Laxative digestion, pile & Fruit,seeds \\
\hline Citrus limon & Lemun tsami & Deworm & Fruit \\
\hline Citrus paradise & Lemu yamiku & Anti body & Fruit \\
\hline Citrus sinensis & Lemun Zaki & Scurvy & Fruit \\
\hline Cocus nucifera & Kwakwa & Anti poison/neutralizes poison, Measles & Nut \\
\hline Cola nitida & Goro & Stimulant & Fruit \\
\hline Combretum micranthum & Geza & Desyntry, Abdominal pain in nursing mother & Leaves \\
\hline Corchorus olitorius & Lalo & Blood purifier & Leaves \\
\hline Crysophylum albedum & Agwaliba & Anti nausea & Fruit \\
\hline Cucurbita maxima & Kabeewaa & Skin disease & Stem \\
\hline Daucus carota & Karas & Pile, blood tonic & Fruit \\
\hline Dialium guinenses & Tsamiyar Biri & Anti ulcer & Fruit \\
\hline Dioscorea alata & Dugura & Fever & Leaves \\
\hline Diospyros mespiliforms & Kanya & Pile, Diarrhoea & Unripe fruit \\
\hline Ealais guinensis & Kwakwan Manja & Easy flow menses & Nut \\
\hline Euphorbia balsamifera & Aliyara & Pile, stomach pain & Leaves \\
\hline Gacinia kola & Namijin Goro & Cough & Fruit \\
\hline Guiera senegalensis & Sabara/Barbarta & Ulcer, Pile & Leaves \\
\hline Hibiscus sabdariffa & Sobo & Anti hepertenstion & Flower \\
\hline Ipomoea batatas & Dankali & Pile & Leaves \\
\hline Jatropha curcas & Cinda zugu & Stomach pain & Leaves \\
\hline Lannea microcarpa & Faru & Dressing wound, swelling & Leaves \\
\hline Lenea acida & Faru & Yellow fever, pile & Leaves \\
\hline Leptadenia hastate & Yadiya & Hypertension,catarrh and skin disease & Leaves \\
\hline Magnifera indica & Mangwaro & Diarrhoea and Dysentry & Leaves \\
\hline Manihot esculanta & Rogo & Diabetics & Tuber \\
\hline Moringa oleifera & Zogala & Abdominal Disorders & Leaves \\
\hline Musa paradisiaca & Plantain & High iron potent astringent & Fruit \\
\hline Musa sapientum & Ayaba & High blood pressure & Fruit \\
\hline Parinari macrophylla & Gawasa & Stomach trouble & Fruit \\
\hline Parkia biglobosa & Kalwa & Snake Venom & Seeds \\
\hline Phoenix dactylifera & Dabino & Worms, bleeding & Fruit,seeds \\
\hline Piper guinenses & Uda & Cleanse womb & Seeds,leaves \\
\hline Psidium guajava & Gwaba & Reduce frigidity/Allergy & Fruit \\
\hline Salonum melongena & Yalo & Kidney problem, pile, lower sugar content & Fruit \\
\hline Solanum lycopersicum & Tumatur & Anti hypertension & Fruit \\
\hline Vernomia amygdalina & Shuwaka & Rheumatic pains & Leaves \\
\hline Xanthosoma sagittifolium & Gwaza & Anti hypertension & Tuber \\
\hline Zingiber officinale & Citta & Detoxify liver bronchitis, cough & corm \\
\hline
\end{tabular}

\section{Discussion}

Result from the study shows that leaves were found to be the most used plant part for medicinal remedy. This is in consistent with the findings of other ethno-medicinal studies in Africa like Uganda, Ethiopia and Mali [18].

More than one plant species have been reported to be used by healers in remedy preparation for various ailments. This

Volume 4 Issue 12, December 2015

www.ijsr.net

Paper ID: SUB15244
Licensed Under Creative Commons Attribution CC BY 


\section{International Journal of Science and Research (IJSR) \\ ISSN (Online): 2319-7064}

Index Copernicus Value (2013): 6.14 | Impact Factor (2014): 5.611

could attributed to additive or synergistic effect that they could have during treatment [19].

Ethnobotany is very helpful in identifying and solving conservations issues, as in cases where the harvesting rate exceeds the re-growth rates. It is prosperous to conserve the medicinal plants, which were harvested [20]. This is in favor of the coming generations, so that they could benefit from this treasure of God, which is a real gift and blessing of nature for mankind. In modern times it is alarming that the knowledge of ethnobotany is disappearing rapidly. Westernization, collapse of traditional cultures and yet the destruction of entire ethnic groups are to blame [21]. A principal aim of such a study is to make sure that local natural history becomes a living tradition in communities; it is being transmitted rally from time to time. The results of this work can laterbe applied to biodiversity, conservation and community development [22], [23].

The procedure used in this study was similar to that of [24] who studied the ethnobotanical potentials of some cultivated plants in Chung region. Anti diabetic potentials of some of these plants cited in this study have been previously reported [25], [26]. The anti diabetic activity of aqueous leaves of Magnifera indica had been reported by [27]. But the antidiabetic effects of other plants like Calotropis procera and Cassia gorantensis have never been reported to our knowledge

\section{Conclusion}

The field of food plant gathering is new in Nigeria in the field of ethnobotany and food plants are neglected in ethnobiological studies especially in the study area. In this research, some plants of medicinal importance more particularly those used in ethno medicine in the study area were assessed; other uses of plant are also mentioned. There is a strong need for collection and documentation of this knowledge, sufficient study is needed

\section{References}

[1] Lowe, H., 2000. Jamaica 's Ethnomedicine: Its Potential in the Healthcare System. Canoe Press, Barbados, NA., ISBN-13: 978-9768125712, Pages: 170.

[2] Schultes, R.E., 1992. Ethnobotany and Technology in Northwest Amazon: A Partnership. In: Sustainable Harvest and Marketing of Rain Forest Products, Plotkin, M., L. Famolare and S. Mori (Eds.). Island Press, Washington, DC., USA., ISBN-13: 978-1559631686, pp: 45-76.

[3] Tor-Anyiin, T.A., R. Shaato and H.O.A. Oluma, 2005. Ethnobotanical survey of antimalarial medicinal plants amongst the Tiv people of Nigeria. J. Herbs Spices Med. Plants, 10: 61-74.

[4] Igoli, J.O., O.G. Ogaji, T.A. Tor-Anyiin and N.P. Igoli, 2005. Traditional medicine practice amongst the Igede people of Nigeria Part II. Afr. J. Trad. Comp. Altern. Med., 2: 134 -152.

[5] Jose San, M.A., 1983. Medicinal plants in central Chile. Econ. Bot., 37: 216-227.
[6] Peters, C.M., A.H. Gentry and R.O. Mendelsohn, 1989. Valuation of an Amazonian rainforest. Nature, 339: 655-656.

[7] Glombitza, K.W., G.H. Mahran, Y.W. Mirhom, K.G. Michel and T.K. Motawi, 1993. Hypoglycemic and antihyperglycemic effects of $<\mathrm{I}>$ Zizyphus spinachristi $</ \mathrm{I}>$ in rats. Planta Medica, 60: 244-247.

[8] Mahabir, D. and M.C. Gulliford, 1997. Use of medicinal plants for diabetes in Trinidad and Tobago. Rev. Panam Salud Publica, 1: 174 -178.

[9] WHO., 1992. Expert committee on specification for pharmaceutical preparation report. World Health Organization (WHO), WHO Technical Report Series, No 823, Geneva, pp: 44-76.

[10] Rao, R.R., 1996. Traditional knowledge and sustainable development: Key role of ethanobiologists. Ethanobotany, 8: $14-25$.

[11] Hamilton, A., 1995. The People and Plants Initiative. In: Ethnobotany: A Methods Manual, Martin, G.J. (Ed.). WWF International, Chapman and Hall, London, UK., ISBN-13: 9780412483707, pp: 10-11.

[12] Maheshwari, J.K., 1983. Development in ethnobotany Editorial. J. Econ. Taxon. Bot., 4: 1-4.

[13] Tripathi, Y.C., 2000. Ethnomedicinal treasure of tribal Rajasthan. J. Non-Timber Forest Prod., 7: 77 -84.

[14] Martin, G.J., 1995a. Ethnobotany: A People and Plants Conservation Manual. Chapman and Hall, New York, USA.

[15] Cotton, C.M., 1996. Ethnobotany: Principles and Applications. John Wiley and Sons Ltd., Chichester, New York, USA., ISBN-13: 978-0471955375, Pages: 424.

[16] Alexiades, N.M. and J.W. Sheldon, 1996. Selected Guidelines for Ethnobotanical Research: A Field Manual. New York Botanical Garden, New York, USA., ISBN-13: 978-0893274047, Pages: 306.

[17] Yirga, G., 2010. Assessment of indigenous knowledge of medicinal plants in Central zone of Tigray, Northern Ethiopia. Afr. J. Plant Sci., 4: 6-11.

[18] Togola, A. and Diallo, D. (2005). Ethnopharmacological survey of different uses of seven medicinal plants from mali (West Africa) in the region of Doila, Kolokaini, and Siby. Jounal of ethno biology and ethno medicine 1:7

[19] Haile Yineger and Delenasaw Yewhalaw (2007). Traditional medicinal plant knowledge and use by local healers in Sekoru district, southwestern Ethiopia. Journal of Ethnobiology and Ethnomedicine 3(1):24

[20]Bopana, N. and S. Saxena, 2007. <i>Asparagus racemosus $</ \mathrm{i}>$-ethnopharmacological evaluation and conservation. J. Ethnopharmacol., 110: 1-15.

[21] Bussmann, R.W. and D. Sharon, 2006. Traditional medicinal plant use in Northern Peru: Tracking two thousand years of healing culture. J. Ethnobiol. Ethnomed., Vol. 2.

[22] Martin, G.J., 1995b. Ethnobotany. Chapman and Hall, London, UK.

[23] Qureshi R. and G.R. Bhatti. 2009. Folklore uses of amaranthaceae family from Nara desert, Pakistan. Pak. J. Bot., 41(4): 1565-1572.

[24]Ahmad, M., M.A. Khan and R.A. Qureshi, 2003. Ethnobotanical study of some cultivated plants of 


\section{International Journal of Science and Research (IJSR) \\ ISSN (Online): 2319-7064}

Index Copernicus Value (2013): 6.14 | Impact Factor (2014): 5.611

Chhucchh region (District Attock). J. Hamdard Medicus, 3: 15-19.

[25] Ojewole, J.A., 2006. Antinociceptive, antiinflammatory and antidiabetic properties of of Hypoxis hemerocallidea Fisch. and C.A. Mey. (Hypoxidaceae) corm [,African potato'] aqueous extract in mice and rats. J. Ethnopharmarcol., 103: 126-134.

[26] Aderibigbe, A.O., B.A. Emudianughe and B.A. Lawal, 1999. Antihyperglycaemic effect of Mangifera indica in rat. Phytother. Res., 13: 504-507.

[27] Matin, A., M.A. Khan, M. Ashraf and R.A. Qureshi, 2001. Traditional use of herbs, shrubs and trees of Shogran Valley, Mansehra, Pakistan. Pak. J. Biol. Sci., 4: $1101-1107$. 